\title{
FROM THE HINTERLAND: COMMEMORATING THE CENTENARY OF WORLD WAR I IN BOHINJ
}

\author{
Tatiana Bajuk Senčar \\ Institute of Slovenian Ethnology \\ Research Centre of the Slovenian Academy of Sciences and Arts, Slovenia \\ email: tatiana.bajuk@zrc-sazu.si
}

\begin{abstract}
The centenary of World War I has been marked by a broad range of commemorative practices across Europe. This has also been the case in Bohinj, a region located in the Julian Alps in the northeastern corner of present-day Slovenia. This article is an examination of the diverse practices of commemoration and heritagization of World War I in Bohinj against the backdrop of contemporary global developments that frame the centenary: the rise of war tourism and the globalization of heritage as an evermore important element of identity construction as well as the political economy of tourism. To what extent do these contemporary trends inform the specific nature of current commemoration and heritagization practices? Their study - together with an analysis of the actors that produce, enact, resist or promote them - aids in identifying and analyzing the diverse social processes that shape Bohinj's present landscape of war heritage.
\end{abstract}

Keywords: Bohinj, commemoration, heritagization, hinterland, Isonzo Front, tourism, World War I

\section{INTRODUCTION}

The centenary of World War I has been marked by a broad range of commemorative practices across Europe. This has also been the case in Bohinj, a region located in the Julian Alps in the northeastern corner of present-day Slovenia. Bohinj's residents experienced World War I in a number of ways: from being drafted to fight in faraway frontlines, staying home to maintain farms and households, to working in diverse ways in the hinterland supply system set up in Bohinj for the Isonzo Front. These multiple - overlapping, diverse - experiences point to the complex social reality of Bohinj during these years, a reality that has been invoked in numerous ways in the course of this important anniversary. 
This article ${ }^{1}$ is an examination of the diverse practices of commemoration and heritagization (Hewison 1987; Walsh 1992) of World War I in Bohinj against the backdrop of contemporary global developments that frame the centenary. These include the rise of war tourism (Butler \& Suntikul 2013; Kovacs \& Osborne 2014) and the globalization of heritage as an evermore important element of identity construction as well as the political economy of tourism (Bendix 2008; Kirshenblatt-Gimblett 2004; Salazar 2012). These overlapping processes reflect a rising interest in the past, which manifests itself in multiple, interlocking spheres (Macdonald 2013), including those of memory, identity, and heritage. To what extent do these contemporary trends inform the specific nature of current World War I commemoration and heritagization practices (Jansen-Verbeke \& George 2013)? Their study - together with an analysis of the actors that produce, enact, resist or promote them - aids in identifying and analyzing the diverse social processes that shape Bohinj's present landscape of war heritage.

This question builds upon a broad range of research on the ways in which World War I commemorative practices have shifted over time and across contexts, expressing particular priorities and values (Ashley 2016). For example, monuments built soon after the war often had a more personal purpose, as they were meant to be sites at which people could mourn their loved ones lost to the war, while later monuments were built to honor all those who sacrificed their lives for the nation and the empire (Winter 1995).

Researchers of World War I commemorations have also highlighted the contested nature of memorials and memorial practices, and the selection of memories, actors, and experiences they were meant to articulate, which implied that memorial practices were inevitably accompanied by acts of forgetting. The practices of forgetting are also context-specific. For example, numerous researchers (e.g. Fussell 1977 [1975]; Mosse 1990) have depicted the erasure of the traces of war from the physical landscapes soon after the war - including the landscape of battlefields - which was meant to help societies return to normal life. This trend was later reversed with the restoration of war landscapes and the creation of open-air museums (Winter 2009), which form an integral part of the contemporary range of commemorative landscapes and were also the sites for a number of World War I centenary events. These sorts of developments can also be seen in Slovenia, which has in recent decades rebuilt and restored sections of the Isonzo Front that have been linked together to form a memorial hiking trail called The Path of Peace, of which Bohinj became a part in 2015 a central event in Bohinj's World War I centenary celebration.

Assessing the role of contemporary trends and broader-based processes in a specific locality such as Bohinj requires the framing of centenary events against the backdrop of existing wartime experiences of social actors as well as within 
the broader history of commemorative practice. This facilitates the identification of continuities as well as changes over time. Furthermore, focusing on social actors and groups and their operation on numerous scales - local, regional, transnational - provides the foundation for teasing out specific features of these practices and the nature of their links to global trends. Thus the ethnographic analysis of Bohinj's marking of the World War I centenary follows upon a brief history of Bohinj's wartime experience and of World War I commemoration and heritagization practices - both tangible and intangible - with an emphasis on the period from Slovenia's independence onwards.

\section{WORLD WAR I AND THE PRODUCTION OF BOHINJ AS A HINTERLAND}

Bohinj's experience of the war can be divided into three phases: 1914-1915, during which time Bohinj's able-bodied men were mobilized, trained, and sent off to war (most of them to the Russian front); 1915-1917, from the point Italy entered the war to the last battle of the Isonzo Front; and the third from 1917 to the end of the war in 1918. At the onset of the war, the Austro-Hungarian army imposed a zoning system onto the imperial landscape, of which presentday Slovenia was a part. In so doing they demarcated combat or battle zones (Kriegsgebeit) - in which the army exercised absolute authority - and outlying areas (Hinterland). Combat zones were broken down further into operational combat regions (Operationsbereich) and intermediate/buffer regions (Etappenbereich), defining them primarily in accordance to their proximity to ongoing conflicts (Budkovič 1999).

Italy's entrance into the war brought with it the opening of a new frontline, the Isonzo Front, located within the Posočje region of present-day Slovenia. In addition, it also resulted in a re-zoning of Slovenia, with Bohinj falling within a so-called buffer/intermediate region (Etappenbereich), meaning that it was to operate as an intermediary area between the zone of combat, strictly speaking, and the outlying regions. Once Italy had entered the war, the military command defined hinterland supply systems for each section of the Isonzo Front. Bohinj became part of one such system due to its position along the railway and its relative proximity to part of the frontlines. Bohinj thus played an important role in the transport of supplies and soldiers to a certain part of the front, a region behind the frontlines for training troops before sending them to the front and caring for the sick and wounded.

Hinterland supply systems in general and that of Bohinj in particular were responsible for providing virtually everything needed on the front, a difficult 


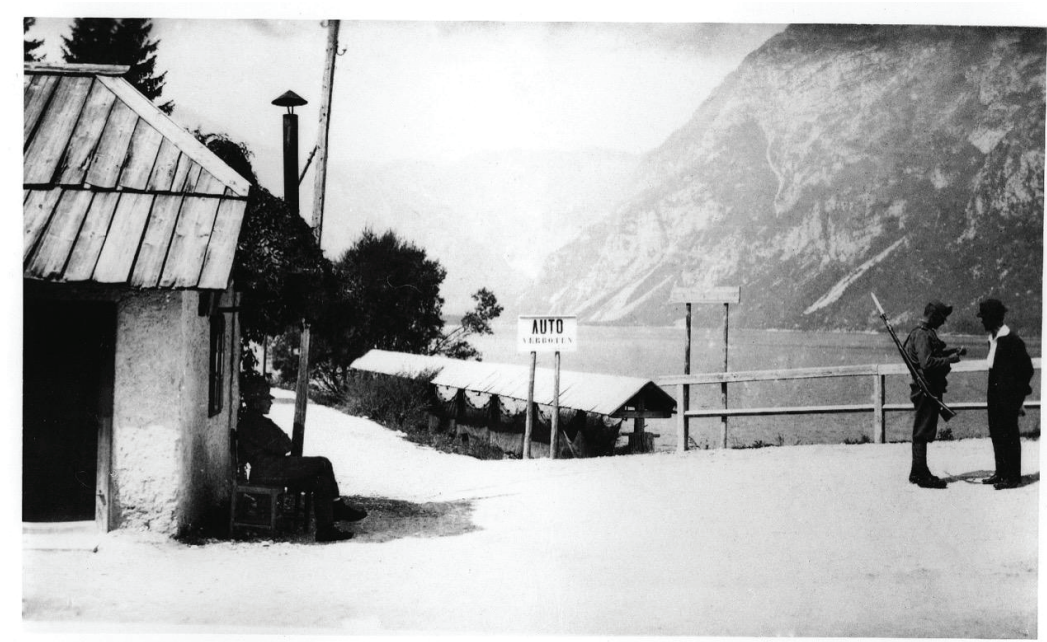

Figure 1. A military police officer inspecting the documents of a civilian before entering the restricted zone by Lake Bohinj. The documents of soldiers and civilians who entered the restricted zone of the hinterland system were thoroughly inspected. Courtesy of the National Museum of Contemporary History, Slovenia.

task given that the front was located in remote, mountainous terrain. Local historian Tomaž Budkovič in his research on Bohinj's role as a hinterland supply system estimates that five persons were necessary to provide everything needed for each soldier on the frontlines (Budkovič 1999). This included basics such as clothing, food and water, medicines, heating materials, lighting materials, construction material, motor fuel, and of course ammunition. Given that Bohinj also served as a training center and the place that provided medical care and convalescence for the wounded, it was in most respects the last stop for soldiers before going to the front and the first stop upon leaving the front.

The incorporation of Bohinj into a hinterland supply corridor brought with it significant changes. At the outset, the route for the supply corridor was primarily composed of badly maintained roads, and a significant part of it via mountainous terrain. Considerable effort was expended to build the necessary infrastructure to make the system work effectively.

This included a narrow gauge railway through the valley that was later powered by electricity as well as the necessary power plant, the expansion of footpaths through mountainous terrain to allow for the transportation of supplies, and finally, the building of a cable-car system. The infrastructure built for the supply system also included a number of buildings, from supply warehouses by the railway, barracks for soldiers as well as for prisoners of war, and 
numerous buildings with different functions in the mountain supply camps. In addition to the new buildings erected all along the supply corridor, a number of existing structures were also adapted to serve diverse purposes in the hinterland supply system. For example, hotels and castles were transformed into hospitals, and the agricultural cooperative centers and the municipal center became rehabilitation facilities. In essence, in a few short years, an entire system was put in place in Bohinj, which transformed daily life for those residents who were not mobilized into combat.

What did the creation of a supply system in Bohinj imply in terms of wartime experience for those who lived there? Most importantly, it implied the incorporation of an exceptionally broad range of social actors - besides local men mobilized onto far-off frontlines - into the daily life of war. Bohinj residents were involved in building the infrastructure necessary for the supply corridor through the Bohinj Valley and in the mountainous terrain, the operation of the supply corridor, the training of soldiers, the housing of officers or the care for the wounded. Furthermore, thousands of soldiers also came through Bohinj, some solely on the way to the frontlines, others stayed longer for either training or convalescence. Those soldiers who did not survive wounds or disease remained buried in Bohinj's military cemeteries. How have these experiences been remembered in the years after the war, and more importantly, during the war centenary?

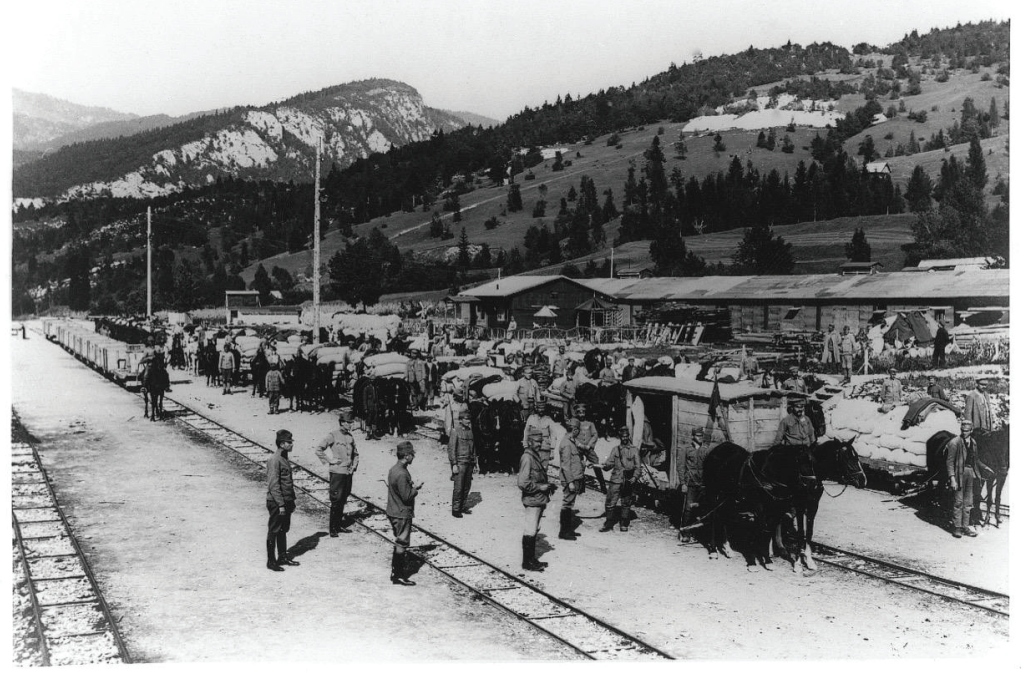

Figure 2. The first station of the narrow gauge horse-drawn railway in Bohinjska Bistrica. Courtesy of the National Museum of Contemporary History, Slovenia. 


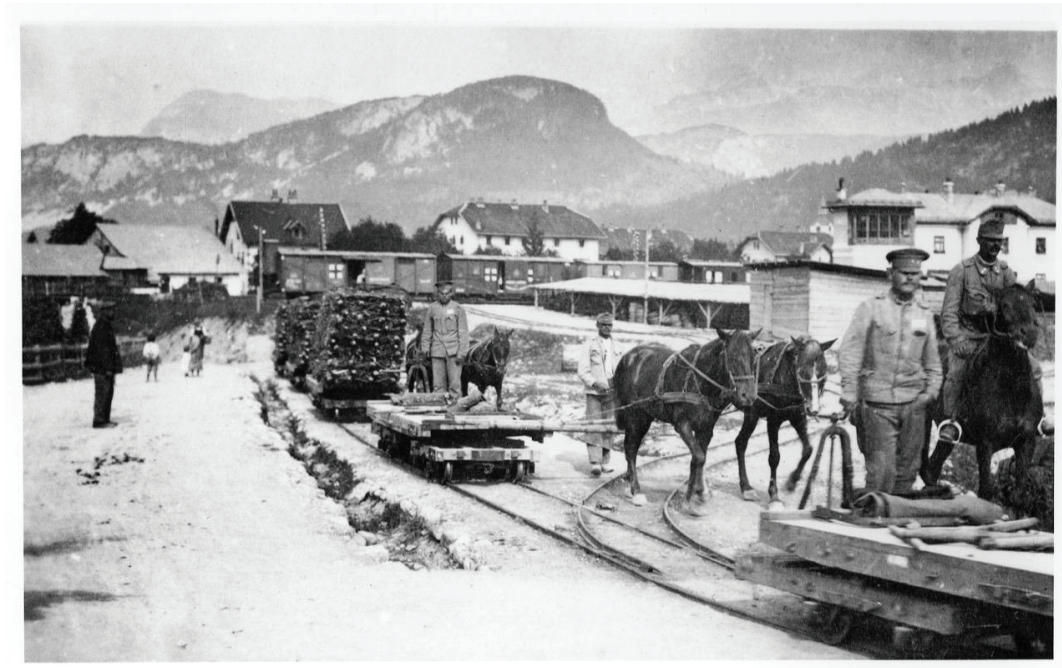

Figure 3. Narrow gauge horse-drawn railway, 1915-1916. The horse-drawn railway was the first section of the hinterland supply system, which ran from the train station to the eastern end of Lake Bohinj. Courtesy of the National Museum of Contemporary History, Slovenia.

\section{COMMEMORATIVE PRACTICES OF WORLD WAR I}

Practices aimed at honoring the fallen began already during the war by erecting monuments to those Bohinj soldiers who had lost their lives as well as by establishing military cemeteries for those soldiers who had died in Bohinj from battle wounds or diseases. Before World War II, two monuments were built near the village churches of Koprivnik and Srednja vas in the memory of the parishioners who had lost their lives in battle. Three military cemeteries were actually established during the course of World War I. The first one was in Bohinjska Bistrica, where they buried those who had died in the military hospitals that operated in the village in 1915-1917. The second cemetery, located in the village of Ukanc, is the final resting place for soldiers who died on the Isonzo Front close to Bohinj (Mt. Krn) and in Ukanc, as well as for a small number of prisoners of war. The third cemetery was located in the alpine meadow Planina na Kraju, which was the final resting place primarily for Hungarian soldiers. These remains were, however, moved before the beginning of World War II and stored in an ossuary built in the shape of a pyramid in the same area (Budkovič 1999). 


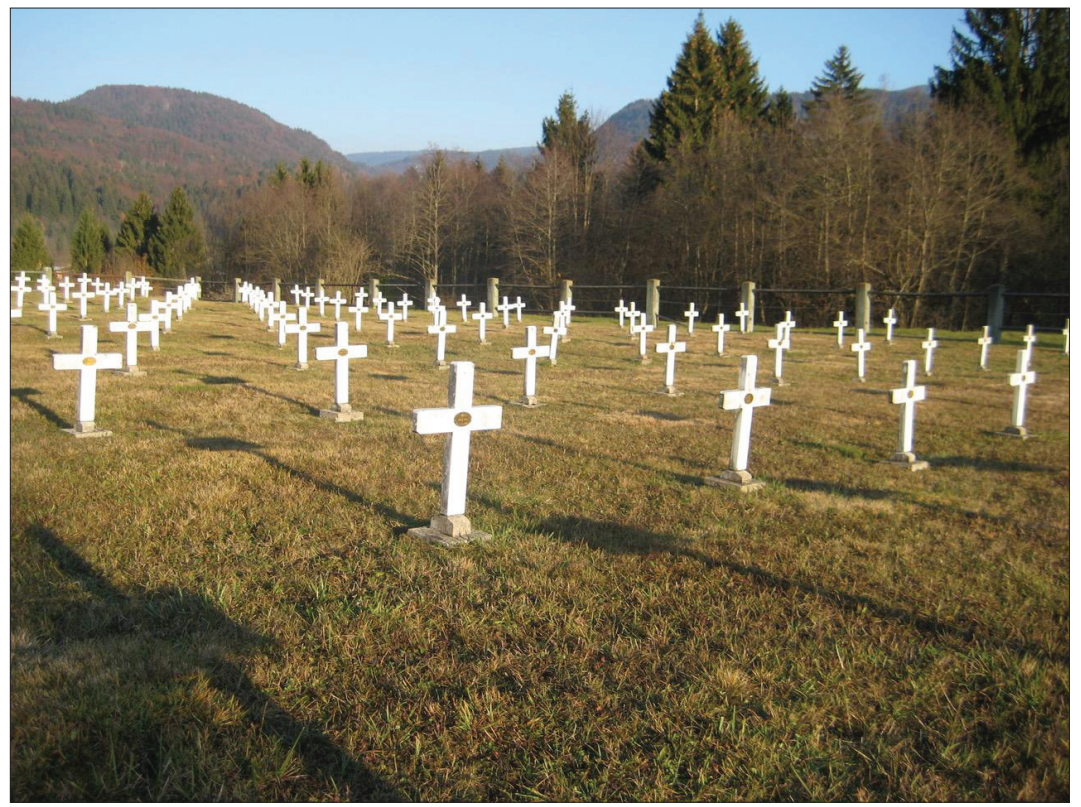

Figure 4. World War I military cemetery Rebro in Bohinjska Bistrica. The cemetery comprises 285 marked graves of Austro-Hungarian soldiers and Russian prisoners of war. Photograph by the author 2016.

For many decades, these monuments and cemeteries were the primary sites of any memorial practices or services dedicated to honoring those who had lost their lives in the war. Most of them were organized as part of November 1 holiday, dedicated to remembering and honoring the departed, and can be divided into two categories: those held for Bohinj soldiers who had lost their lives in the war, and those held at military cemeteries for the soldiers who had died in Bohinj. The former were organized primarily at existing monuments and consisted mainly in the laying of wreaths. In recent years, the commemoration ceremonies conducted at the military cemeteries have become more elaborate, particularly the one that has been held at the military cemetery in Ukanc since 1993. A local tourist association that was entrusted with the upkeep of the cemetery has been organizing another event for several years, one that has been intended for a much broader audience. One of the persons most actively involved in this ceremony, which is hosted by the tourist association along with the municipality, explains that ambassadors of all the nations whose soldiers are buried in Bohinj are invited. ${ }^{2}$ These include Hungary, Austria, Italy, Poland, Ukraine, Czech Republic, Slovakia, Romania, Russia, Croatia, Bosnia, Serbia and Montenegro. Attendance fluctuates from one year to the next; however, ambassadors 
from certain countries - Hungary, for example - are always present. National representatives, while invited, are absent, usually sending a wreath. The entire ceremony, led by the parish priest of Srednja vas and hosted by the mayor of Bohinj, lasts almost an hour. The ceremony is meant to preserve the memory of all those who are buried here and to promote a message of peace: to remember what happened so that it may never happen again.

Numerous other practices emerged in later decades, which focus primarily on what happened to Bohinj and its residents during the war and how the war became etched into landscapes, local experience, and social memory. One such practice involved the collection of material artifacts, originating from the Bohinj landscape and preserved and passed down through generations. Local actors played an important role in this regard: for example, Tomaž Budkovič, a geologist by profession, had a passion for local history and was an avid collector of war artifacts. Together with his colleagues Janko Stušek and Lovro Vojvoda, he collected the artifacts to create Bohinj's first World War I museum called Mali vojni muzej (Small war museum) in 1989, one of the first museums in Slovenia dedicated to World War I.

The 1990s also marked an increase in diversity among commemorative practices, including the collection of material artifacts, the production of local wartime history, and the organization of memorial hikes to the frontline region. Local figures were key to the production and dissemination of local World War I history. One of the most prominent figures is Tomaž Budkovič, who was one of the founders of the Bohinj's World War I museum. When the museum was opened in 1989, Budkovič was asked to write a brochure for the collection, which became a source of inspiration for the first historical monograph on Bohinj's World War I history, providing a detailed description of its role as a hinterland system for the Isonzo Front (Budkovič 1999). He is recognized as one of the leading experts on local history and has written numerous books on Bohinj's twentieth-century history. He wrote a second book on World War I on the eve of the centenary, based on the correspondence between a Bohinj soldier who fought on the Isonzo Front and his family (Budkovič 2014).

Another important practice involves the compilation of oral histories in the form of narrated experiences. While local historical sources focusing on World War I that centered on the local daily life in Bohinj during the war were based primarily on existing written sources (both local and non-local), oral history focused on daily life experiences as they have been preserved in narratives. Marija Cvetek, a local ethnologist and linguist, has compiled an anthology of 53 such narratives, transcribed in the local dialects (Cvetek 2014) of Bohinj's numerous villages. They depict many facets of life experience during the war, including seeing off those mobilized to the frontlines, carrying on daily life in 
the face of the absence of those gone off to war, dealing with the presence of foreign soldiers in the valley - and even in one's homes.

A final commemorative practice that also has had significant implications for the heritagization of Bohinj's World War I experiences is linked to hiking in the mountainous region along the Isonzo frontline as a way of remembering those who fought and perished on the front. Local alpine clubs, veteran organizations, and local police chapters decided to organize the first such memorial hike to Lake Krn to commemorate the end of World War I and those fallen on the Isonzo Front in 1997. While this memorial walk under the name "Krn - pohod spomina / Krn - memorial hike" initially involved local clubs, organizations, and chapters in the immediate vicinity of the Isonzo Front line, it soon took on broader dimensions as organizations from Bohinj, including the local alpine clubs and the war museum, also participated in the memorial hike from the Bohinj Valley. In addition, national and international officials also attended the memorial services. The memorial hike has continued to be held every year through to the present day.

\section{HERITAGIZING BOHINJ'S WARTIME EXPERIENCE}

Slovenia's declaration of independence in 1991 represents an important historical milestone in the commemoration of World War I, as it was in this period that certain elements or practices became subject to heritagization. By heritagization I mean the metacultural processes that allow for a negotiation and revalorization of the past for the constitution of a community and a collective identity in the present (Herzfeld 2010; Kirshenblatt-Gimblett 2004). The cemeteries in Bohinjska Bistrica and Ukanc were accorded the status of cultural monuments and have undergone restoration and renovation, which marked the beginning of the World War I heritagization in Bohinj at the national level. Local level, bottom-up processes carried out by local actors are more diverse in nature and are related to the growing significance linked to remembering and reframing Bohinj's World War I history and experience in the public sphere.

One could consider the creation of the Mali vojni muzej in 1989 not only an act of public commemoration but also of heritagization, as collections of material artifacts are presented in the museum for the public. It presently forms part of a larger museum - the Tomaž Godec Museum in Bohinjska Bistrica - that houses numerous exhibits related to Bohinj's history. The museum is of course presented as one of Bohinj's tourist attractions and has been incorporated into the regional association of museums in the Gorenjska region of Slovenia. Another significant practice of heritagization in this regard concerns the extent to 
which local tourism actors incorporate World War I historical sites as significant sites on tours of Bohinj. A local tour guide that I spoke to mentioned that war cemeteries were often neglected during tours of Bohinj - it is rather ironic, as the war cemetery of Ukanc is located in a wooded area only a few hundred meters from Lake Bohinj, and thus hard to overlook. However, this attitude has changed in recent decades, and the tour guide explained:

Many of us, when we put together a program, include the cemetery especially if we have a group, and especially that of foreigners. If we take them to the Vogel [ski lift], there is a footpath to the lake that takes you past the cemetery, so it is a logical stop. It can be an important element of Bohinj's tourist image for those of the older generation, if they have some sort of understanding of the war. ${ }^{3}$

Among the largest World War I heritagization projects, one finds a proposal for a thematic hiking trail in Bohinj that is meant to link historically significant sites and routes distinctive to Bohinj's wartime experiences. The idea of this historical thematic route first emerged in the context of the 20th anniversary of Triglav National Park in 2001, but became a concrete proposal when published as part of Bohinj's tourism development program for the years 2006-2013. This is one of a number of hiking trails that were developed to strengthen Bohinj's tourism program, and extends its tourist high season, which is in the summer.

The proposal states that the purpose of the thematic trail was to link all the more interesting sites in the area under the rubric of World War I, the Isonzo Front and its supply system. The idea for a memorial trail was based on three factors: that Bohinj was a supply hinterland for the Isonzo Front from 1915 onwards, that experts identified a number of sites that could be interesting for tourists, and finally, that many tourists and locals were interested in sites linked to the war (Občina Bohinj 2006).

The thematic trail, marked by seven billboards along a route from Lake Bohinj up to the Bogatin supply camp, was inaugurated the following year. The path linked numerous sites along the former supply trail and reframed them as part of the memorial route dedicated to Bohinj's wartime experience, including the supply route itself through the mountains above Bohinj Lake, the military cemeteries and Bohinj's war museum. The inauguration of the thematic trail coincided with the Krn Lake Memorial Hike, and was attended by local hikers, cultural and/or hiking organizations as well as politicians - both from Bohinj and from regions linked to the Isonzo Front (Langus 2007). Inauguration organizers thus claimed a connection between the new thematic trail they had created and the existing commemorative hiking practices carried out in what was the landscape of the Isonzo Front, thus rendering explicit the broader 
framework in which they wished to place Bohinj's new trail. Furthermore, they added a new layer of meaning to the sites they connected by reframing them into a single tourist attraction.

\section{THE WORLD WAR I CENTENARY IN BOHINJ}

It is thus apparent that in recent decades considerable developments have occurred in the production, commemoration, and heritagization of Bohinj's World War I history and experience on diverse levels. How have Bohinj social actors marked the centenary, particularly in relation to the established range of practices mentioned above? Upon looking at the list of events prepared for the different years of the war centenary, one can make a distinction between events that could be defined as new practices particular to the centenary and events that draw upon established practices or are incorporated into them. New practices, for example, included a soccer game organized in remembrance of the game played by soldiers from opposing sides in no man's land during the 1914 ceasefire; local museum exhibits held in Bohinj on different aspects of the war, and a theater production put on by a local theater company.

The majority of the events, however, involve reframing existing memorial sites or being incorporated into existing series of events. For example, one such event was the (re)opening of the renovated Tomaž Godec Museum in Bohinjska Bistrica, which houses exhibitions of Bohinj's natural and cultural heritage, in which the collection of the Mali vojni muzej has found a permanent home. In addition, certain events marking the World War I centenary were incorporated into existing festivals that take place during the course of the year, including the International Wildflower Festival held in late spring, the Bohinj Summer Music Festival, and the Bohinj Hiking Days held in the autumn months.

For example, the International Wildflower Festival in the year 2015 included an exhibition of the work of photographer Peter Strgar on the theme Vojna in cvetje (Flowers and war), in which the photographer portrays the many sorts of relationships between the two. He depicts the important role of flowers in honoring victims of war and how war itself influences the flora of conflict zones, with the mobility of soldiers and livestock facilitating the introduction of new species into the landscape around Mt. Krn above Bohinj Lake (Sodja 2015). Furthermore, a special concert featuring Mozart's Requiem was included in the Bohinj Summer Music Festival program, which was dedicated to all who lost their lives in both world wars, as 2015 marked the 70th anniversary of the end of World War II. 
In addition, one of the most important events was held within the framework of the Bohinj Hiking Days in 2015, marking the incorporation of the thematic hiking trail along the hinterland supply route in Bohinj into a leg of the celebrated Walk of Peace hiking trail along the Isonzo Front. The (re)opening of the memorial trail as a leg of the Walk of Peace was dedicated to the memory of the then recently departed Tomaž Budkovič, who had played such an important role in documenting and memorializing Bohinj's World War I history by different media. It was, in effect, a two-day event that took place in early October 2015 and was organized by local tourism association and alpine clubs. Participants started out to Bogatin (under Mt. Krn) in mid-afternoon, and the ceremony included a cultural program as well as a speech memorializing Budkovič's work. The second day began with a mass for all those who had lost their lives in the war, and the ceremonial opening of the memorial trail as a leg of the Walk of Peace.

The memorial two-day hike to the base of Mt. Krn has been repeated each year. In 2016, Bohinj organized a similar two-day event to conclude its yearly Hiking Festival, and once again the event had a strong commemorative theme as it centered on Marija Cvetek's recently published collection of oral histories about the wartime experiences of Bohinj men and women during the war (Cvetek 2014). The theme of the 2017 memorial hike was the hundred-year anniversary of the battle of Kobarid (Caporetto) as a turning point in the Isonzo Front battles and its effect on Bohinj, given that the frontlines moved significantly eastward, towards the Piave River. The schedule included a talk given by Lojze Budkovič - Tomaž Budkovič's brother - about a neglected aspect of World War I hinterland history associated with the Sava Line, which was the final line of defense behind the Isonzo Front that also ran through Bohinj.

\section{COMMEMORATION, HERITAGIZATION, TOURISMIFICATION}

Stepping back to assess the numerous events that have been organized in the last years and dedicated to marking the World War I centenary, two things become clear. First, there is a strong continuity between past and present memorial practices, and the program marking the World War I centenary in Bohinj is rooted in established commemorative traditions. Second, there is no apparent break or discontinuity with the past when analyzing how Bohinj memorializes the centenary as a particular anniversary. In fact, it seems that remembering the war centenary has been incorporated into numerous aspects of public life in Bohinj, including the programs offered to Bohinj's visitors/tourists. It is, however, this ever-stronger association between tourism events and festivals 
and war commemoration that begs the question as to how contemporary trends in heritage management and tourism - war tourism, heritage tourism - inform the way that Bohinj actors decide are memorializing the centenary. What effect does the touristic framing of World War I commemoration have on how and why Bohinj residents remember local war experience and portray it to chosen audiences?

Most of the events that took place in Bohinj to mark the centenary were more commemorative than touristic in nature. The majority of them were presented as part of a nation-wide series of events marking the centenary of the Isonzo Front, and a national committee oversaw its organization and implementation. Bohinj's collaboration with the national committee and the purpose of the events is also apparent in the introductory wording of the schedule for the events of 2015 :

On the anniversary of the beginning of the fighting on the Isonzo Front, we prepared a selection of events in cooperation with diverse organizations and associations with the purpose of remembering those cruel times and warning that history can repeat itself at any time; as a result, striving for peace should be one of the main missions of modern society. (Turizem Bohinj 2015)

The majority of events outlined in this schedule seem to have been intended primarily for the local or - at the broadest level - the national audience. Events were carried out primarily in Slovene; they took place in different local centers throughout Bohinj (including the local library, the municipal cultural center, and the local elementary schools), were carried out by social actors, and aimed at highlighting diverse aspects of local wartime experience in Bohinj. For example, the presentation of the collection of local oral history narratives, transcribed and collected by Marija Cvetek, was held in the municipal cultural center on 14 March 2015. The presentation included Marija Cvetek's reading of chosen narratives in local dialects as well as local actors' testimony of their parents or grandparents in the war. This presentation was repeated in the following weeks at the local elementary school, demonstrating the role of this collection as a means of presenting and transmitting local history and experience (Repinc 2015).

While certain scheduled events highlighted local features of the war, they also had a broader message that involved linking this local dimension to the story of the Isonzo Front and framing Bohinj's experience as a hinterland to the front. For example, the museum exhibit titled "Zdrav sem in dobro se mi godi / I am healthy and doing well”, organized by the Žiga Zois Museum Society, focused on propaganda in the Bohinj hinterland (Turizem Bohinj 2015). The re-opening 
of the World War I exhibit in the renovated Tomaž Godec Museum, dedicated to the hinterland supply system and the inauguration of the memorial trail as a leg of the Walk of Peace, would also fall into this category.

There were a number of events that transcended the language barrier and thus could be accessible to a broader audience. Furthermore, they also took place during the high season, when non-local actors were bound to be present; for example, the art and photography exhibitions as well as the temporary museum exhibits, some of which remained open also during the summer months. One such example was the exhibit titled "Proti vojni / Against War", by the artist Franc Rasinger in the Tomaž Godec Museum, which remained open during all the summer months. The pieces involved the superimposition of verses in Glagolitic Slavic script on collages of news headlines and war photographs meant to depict the senselessness of war, in itself a global message.

The range of intended audiences, however, did not necessarily define the range of meanings accorded to any given event. In fact, the most internationally-defined event - if one takes into account the range of participants - is the commemoration held on November 1 at the military cemetery in Ukanc. As was mentioned earlier, local officials and host organizations invite ambassadors from most of Europe to pay homage to those who lost their lives and are buried in the cemetery, far away from their homeland. The majority of the soldiers are Hungarian, and in recent years an organization called The Krajczáros Alapítvány Foundation has played an increasingly large role in maintaining the cemetery and the graves of Hungarian soldiers in Bohinj, including contributing funds for renovation and sending volunteers to help with the physical upkeep of the cemetery. Foundation representatives as well as the Hungarian ambassador to Slovenia have historically had a significant role in the November 1 ceremony, including a speech as well as a musical accompaniment. Thus, while the significant presence of Hungarian groups and political representatives renders this particular ceremony unique in Bohinj, this does not necessarily imply that it is meant to engage different sorts of audiences outside the commemorative sphere.

The fact that certain events were incorporated into established tourism festivals suggests that organizers were striving to address a broader audiencewhat sorts of changes did this imply? What does this mean for the events' commemoration dimensions? These questions become particularly relevant when analyzing one of the events whose reframing speaks most to the issue of potential tourismification - the two-day memorial hike along the memorial trail along the hinterland supply route that was (re)inaugurated as a leg of the Path of Peace trail. The rebranding of the trail and its dedication to the memory of Tomaž Budkovič provided a forum not only for memorializing an important chapter of 
local and global history but also for celebrating the efforts of Bohinj local actors who have contributed to the preservation of Bohinj's wartime heritage - all of which falls within the scope and spirit of the Walk of Peace brand, which speaks both to the war commemoration and heritagization. But what can be said thus far about the tourismification of Bohinj's wartime heritage?

By tourismification I am referring to what Wang describes as "processes by which society and its environment have been turned into spectacles, attractions, playgrounds, and consumption sites" (Wang 2000: 197). Some theorists argue that the passing of time has facilitated the heritagization and/or tourismification of war sites and landscapes, based on their transformation from what Jansen-Verbeke and George term "private inheritance to collective claims" (Jansen-Verbeke \& George 2013).

Numerous researchers have demonstrated that the tourismification of local cultural landscapes can have negative or positive consequences, in some cases empowering and even promoting the resurgence of local identity. The impact of these changes is linked to the social and institutional actors making collective claims and the nature of the claims themselves. The sorts of actors, agendas, and measures taken to create a tourismified landscape at diverse scales can ultimately shape how this landscape is defined, promoted, and implemented. At the same time, the political and symbolic economy of the global tourism industry inform the extent of effective local agency. All of this implies that the concepts of top-down and bottom-up tourismification initiatives are not as discrete as they seem to be; nor are they mutually exclusive.

One such important factor that informs this dynamic in this case is the brand of the Walk of Peace itself, to which Bohinj actors lay claim with their renaming of the memorial hiking trail. The Walk of Peace trails in this region of Europe have a particular history. According to existing sources, the concept of the Peace Trails in the Alps is mainly the work of Austrian alpinist and military historian Walther Schaumann, who in 1973 began to work on restoring World War I landscapes in the South Tyrolean mountains and making them accessible to visitors under the label Peace Trail. In addition to the Walk of Peace in Slovenia, only two other trails have been granted permission to use the Walk of Peace brand: the Dolomitenfreunde Peace Trails in Austria and the Itinerare di Pace sul Carso della Grande Guerra in Italy. Each of these hiking trail projects operates under a similar premise - transforming what were ruins or traces of conflict into sites of wartime heritage while also arguing for the importance of peaceful cooperation in a borderland region (Wohlmuther \& Wintersteiner \& Wagner 2014). Being able to use the Peace Trails brand is contingent upon presenting local and distinctive wartime landscapes in an accessible manner 
while promoting peace as a universal value. The brand seems to imply certain limits for peace trails as tourist attractions; however, the issue of how these limits are negotiated at the local level is one that requires further and more long-term research, as Bohinj has a very short history with the brand.

In addition to employing the memorial trail as a site for centenary commemorations, local tourist actors who have been involved in the creation and rebranding of the trail have additional expectations regarding the rebranded trail. One high-level tourist official remarked:

This new thematic trail also represents a link that will help bring together local tourist organizations from both regions. The Walk of Peace in the Posočje region is also connected to other hiking trails, such as, for example, the Alpe Adria Trail, and thus is able to attract many guests. This interconnection among hiking trails is very important, as the target group of tourists, who are interested in such trails, is quite large. ${ }^{4}$

This tourism official talks of forging connections in terms of tourism development and as a means or route for attracting increasing numbers of tourists and, more importantly, new groups of tourists, mobile actors who travel along particular routes to which Bohinj tourism wishes to connect. The creation of thematic, memorial paths forms part of a broader project of tourism development, with which Bohinj strives to expand its tourism season - which is condensed to a high season in the summer and a shorter one in the winter - with the aid of new tourist attractions (Bajuk Senčar 2015). How will these new forms of collaboration inform the evolution of the tourist landscape in Bohinj, and how will these sorts of connections inform the way that Bohinj operates as a commemorative landscape?

\section{CONCLUDING THOUGHTS: FORGING CONNECTIONS}

Contemplating the sorts of tourist connections that actors in Bohinj wish to generate and the potential impact that these connections (could) have on Bohinj - and potentially transforming it into a spectacle, playground or consumption site, to paraphrase Wang - should not take place in a vacuum. It is apparent that against the backdrop of the centenary Bohinj has become a site of numerous claims and practices of connection linked to the war during the centenary, not all of them being primarily touristic in nature. These largely operate as responses to the processes of displacement that shaped so much of the wartime experience. Bohinj men were sent off to war, many of them never to return, their resting places far from home. The memorials dedicated to Bohinj's soldiers are meant to honor their sacrifice, but also mark their (physi- 
cal) absence. On an analogous level, the military cemeteries in Bohinj provide a final resting place for soldiers who were also mobilized to fight on frontlines in foreign lands - with Bohinj locals operating as caretakers for a memorial dedicated primarily to those whose final resting place is located far from home. In addition, Bohinj's success as a key link in the hinterland supply chain and as a site for training and convalescence hinged on its operations as an effective system for the transportation of supplies and personnel along an established route, only traces of which are visible today.

Bohinj's efforts in commemorating the war in numerous ways and these processes of displacement involve identifying, marking, and honoring both present and absent wartime actors as well as conferring significance to traces of a wartime hinterland system. Upon analyzing the events and practices depicted over the course of this article, it becomes clear that the social actors who organize and perform them claim or enact some form of connection to these experiences. These claims articulate links to a particular landscape, to a shared history or heritage (local, national, global), links between hinterland and frontlines, and even to a common, global message of peace. The centenary as a landmark anniversary has become an opportunity to forge connections through diverse gatherings and practices - and in some cases, diverse forms of connection at the same time.

Thus the sorts of links that tourist actors try to forge with the reframing of the memorial trail along the hinterland supply route in an attempt to spur tourist development are set in a commemorative and touristic landscape informed by numerous registers of connection and collaboration. In certain cases, it is difficult to separate the commemorative from the touristic, as Bohinj's wartime history and experience has become an increasingly significant element of Bohinj's heritage as well as its identity, particularly its identity as a tourist destination.

Upon analyzing the range of events and practices that marked the World War I centenary, it becomes clear that Bohinj is not immune to contemporary global developments, including the rise of war tourism and the increasingly important role of heritage in numerous spheres of daily life. However, these developments - particularly if one assesses them in conjunction with the actors involved in their operation - have strong ties to established local forms of commemorative and touristic practice. In addition, certain regional and even transnational factors to which existing touristic forms of commemoration are now linked - including the limits of the Walk of Peace brand and the multidimensional nature of existing events - inform how war tourism has developed thus far in Bohinj. Time will tell what different forms of touristic practice understood as cooperation across physical and political borders will bring to local communities and how these new collaborative touristic practices will potentially inform the production of local wartime social memory. 


\section{NOTES}

1 The article is based on the research carried out for the research project titled Heritage of the First World War: Representations and Reinterpretations (2016-2018), funded by the Slovenian Research Agency (No. J6-7173). For more information about the project see Jezernik \& Fikfak 2018.

2 Anonymous interview with a local tourism association official. Ribčev Laz, 10 March 2017. During the course of my research in Bohinj, I interviewed approximately 15 people from March to July 2017. They included people in the municipality, in tourist organizations, museums, and other associations involved in the preservation of Bohinj's World War I heritage. The interviews are anonymous.

3 Anonymous interview with a local tourist guide. Bohinjska Bistrica, 12 April 2017.

4 Anonymous interview with a municipal tourism official. Bohinjska Bistrica, 18 May 2017.

\section{REFERENCES}

Ashley, Susan L.T. 2016. Acts of Heritage, Acts of Value: Memorialising at the Chattri Indian Memorial, UK. International Journal of Heritage Studies, Vol. 22, No. 7, pp. 554-567. http://dx.doi.org/10.1080/13527258.2016.1167107.

Bajuk Senčar, Tatiana 2015. The International Wildflower Festival and the Implementation of Sustainable Mobility as Touristic Practice. Traditiones, Vol. 44, No. 1, pp. 87-116. http://dx.doi.org/10.3986/Traditio2015440104.

Bendix, Regina 2009. Heritage Between Economy and Politics: An Assessment from the Perspective of Cultural Anthropology. In: L. Smith \& N. Akagaza (eds.) Intangible Heritage. London: Routledge, pp. 253-269. Available at http://www.academia. edu/8871467/Heritage_between_Economy_and_Politics._An_assessment_from_ the_perspective_of_cultural_anthropology, last accessed on 27 June 2018.

Budkovič, Tomaž 1999. Bohinj 1914-1918: Med fronto in zaledjem. [Bohinj 1914-1918: Between the Front and the Hinterland.] Celovec \& Ljubljana \& Dunaj: Mohorjeva založba.

Budkovič, Tomaž (ed.) 2014. S Turudijevim bataljonom na soškem bojišču: iz pisem poročnika Vladimirja Bregarja. [With the Turudi Battalion on the Isonzo Battlefield: From the Letters of Lt. Vladimir Bregar.] Celovec: Mohorjeva.

Butler, Richard \& Suntikul, Wantanee (eds.) 2013. Tourism and War. London \& New York: Routledge.

Cvetek, Marija 2014. Hude so res vojské...: Bohinjske pripovedi o 1. svetovni vojni. [The Armies Are Dreadful...: Bohinj Narratives on the First World War.] Celje: Celjska Mohorjeva družba.

Fussell, Paul 1977 [1975]. The Great War and Modern Memory. London: Oxford University Press. 
Herzfeld, Michael 2010. Engagement, Gentrification, and the Neoliberal Hijacking of History. Current Anthropology, Vol. 51, No. S2, pp. S259-S267. http://dx.doi. org/10.1086/653420.

Hewison, Robert 1987. The Heritage Industry: Britain in a Climate of Decline. London: Methuen.

Jansen-Verbeke, Myriam \& George, Wanda 2013. Reflections on the Great War Centenary: From Warscapes to Memoryscapes in 100 Years. In: Richard Butler \& Wantanee Suntikul (eds.) Tourism and War. London \& New York: Routledge, pp. 273-287.

Jezernik, Božidar \& Fikfak, Jurij (eds.) 2018. Cultural Heritage of the Great War. Traditiones, Vol. 47, No. 1. DOI: 10.3986/Traditio20184701.

Kirshenblatt-Gimblett, Barbara 2004. Intangible Heritage as Metacultural Production. Museum International, Vol. 56, No. 1-2, pp. 52-65. https://doi.org/10.1111/j.13500775.2004.00458.x.

Kovacs, Jason F. \& Brian S. Osborne 2014. A Bibliography: The Great War (1914-1918). Halifax, NS: World Heritage Tourism Research Network, Mount Saint Vincent University. DOI: 10.13140/RG.2.1.3571.1523.

Langus, Klemen 2007. Nova tematska pot. [New Thematic Trail.] Bohinjske Novice, December, pp. 11-12. Available at https://obcina.bohinj.si/Files/ eMagazine/23/101997/Bohinjske_Novice_december2007.pdf, last accessed on 28 June 2018.

Macdonald, Sharon 2013. Memorylands: Heritage and Identity in Europe Today. London: Routledge. https://doi.org/10.1111/amet.12434.

Mosse, George L. 1990. Fallen Soldiers: Reshaping the Memory of the World Wars. New York \& Oxford: Oxford University Press.

Občina Bohinj 2006. Program razvoja turizma v Bohinju 2006-2013. [Bohinj Tourism Development Program 2006-2013.] Available at https://obcina.bohinj.si/files/ other/news/23/100029Program\%20razvoja\%20turizma\%20v\%20Bohinju\%20 2006-2013.pdf, last accessed on 28 June 2018.

Repinc, Urška 2015. Predstavitev nove knjige Marije Cvetek [Presentation of Marija Cvetek's New Book.] Bohinjske Novice, pp. 9-10. Available at https://obcina. bohinj.si/objava/101821, last accessed on 19 September 2018.

Salazar, Noel B. 2012. Shifting Values and Meanings of Heritage: From Cultural Appropriation to Tourism Interpretation and Back. In: Sarah M. Lyon \& E. Christian Wells (eds.) Global Tourism: Cultural Heritage and Economic Encounters. Lanhan: Altamira, pp. 21-41.

Sodja, Andraž 2015. Odprli Festival alpskega cvetja. [The Opening of the Alpine Flower Festival.] Gorenjski Glas, 27 May. Available at http://arhiv.gorenjskiglas.si/ article/20150527/C/150529832/odprli-festival-alpskega-cvetja, last accessed on 24 September 2018.

Turizem Bohinj $2015=100$. obletnica začetka bitk na Soški fronti. [Centenary of the Commencement of Fighting on the Isonzo Front.] Available at http://www2.bohinj.si/si/ novice/100_obletnica_zacetka_soske_fronte, last accessed on 19 September 2018.

Walsh, Kevin 1992. The Representation of the Past: Museums and Heritage in the Postmodern World. London: Routledge. 
Wang, Ning 2000. Tourism and Modernity: A Sociological Analysis. Oxford: Pergamon Press.

Winter, Caroline 2009. Tourism, Social Memory and the Great War. Annals of Tourism Research, Vol. 36, No. 4, pp. 607-626. http://dx.doi.org/10.1016/j. annals.2009.05.002.

Winter, Jay 1995. Sites of Memory, Sites of Mourning: The Great War in European Cultural History. Cambridge: Cambridge University Press.

Wohlmuther, Cordula \& Wintersteiner, Werner \& Wagner, Mira 2014. Connected by the Trails That Used to Divide Us: Peace Trails in the Alps-Adriatic Region. In: Cordula Wohlmuther \& Werner Wintersteiner (eds.) International Handbook on Tourism and Peace. Klagenfurt: Drava, pp. 321-334. Available at https://www.eunwto.org/doi/pdf/10.18111/9783854357131, last accessed on 29 June 2018. 